Vol. I No. 3 - December 2020

\title{
Can Credit Recipient Household Escape from Poverty?
}

\author{
Tegar Rismanuar Nuryitmawan \\ Research Institute of Socio-Economic Development (RISED),Surabaya, Indonesia \\ rismanuar1994@gmail.com
}

\begin{abstract}
This study aims to answer whether or not financial distribution can play a role in development and poverty alleviation in Indonesia. Households who receive credit are treated as the analysis level and research object. Credit is an instrument to help households escaping from poverty. Some opinions believe that by being given credit, households will be able to boost their economic capacity both in terms of purchasing power or business development capacity. However, to prove this opinion as well as to answer the question, using panel data from the Indonesian Family Live Survey (IFLS) in 2007 and 2014 will attempt to estimate the effect of the probability of households receiving credit on their poverty status. The probability of a credit recipient household will be calculated using Propensity Score Matching so that a similarity score of household characteristics will be obtained between those who get credit and those who do not. Using Double Differences, this study will address the description of changes in household poverty status after receiving credit from financial institutions. The PSM calculations results show that there are four variables as credit recipient household's characteristics, namely collateral ownership, the status of property ownership, history of natural disasters, and gender. Meanwhile, the estimation results on poverty status indicate that credit recipient households have a greater probability of escaping poverty than those who do not receive credit. Therefore, the anti-poverty policy through the transmission of financial institutions is relevant to be prepared. The anti-poverty policy is related to low credit interest rates through government subsidies, public fund placement with low cost of fund, increasing financial literacy and knowledge of the society, and adjusting credit approval based on regional economic conditions.
\end{abstract}

Keywords: Household Poverty, Credit Approval, Impact Evaluation

ARTICLE INFO

Received: Nov 2, 2020

Received in revised form: Nov 23, 2020

Accepted: Nov 23, 2020
JISDeP - The Journal of Indonesia Sustainable Development Planning Published by Centre for Planners'

Development, Education, and Training (Pusbindiklatren),

Ministry of National Development

Planning/ National Development

Planning Agency (Bappenas), Republic of Indonesia
Address: Jalan Proklamasi 70,

Central Jakarta, Indonesia 10320

Phone: +62 $2131928280 / 3192828$

Fax: +62 2131928281

E-mail: pusbindiklatren@bappenas.go.id

Supported by Indonesian Development Planners Association (PPPI) 


\section{Introduction}

Research on poverty shows that there is a significant relationship between financial inclusion and poverty alleviation. The United Nations (UN) has explicitly advocated the development of an inclusive financial system since 2005. The history of financial institutions such as Grameen Bank in Bangladesh, Banco Solidario in Bolivia, Latin America's Village Bank, and Bank Rakyat Indonesia in Indonesia show that financial inclusion is an effective tool for achieving poverty alleviation and sustainable development (Morduch, 1999)

The relationship between the development of financial institutions and poverty alleviation is believed by many to be a good policy. Jaililian and Krikpatrik (2005) studied the impact of financial development on poverty in developing countries. Jaililian and Kirkpatrick (2005) provided empirical evidence about the causal relationship in the scheme of poor households' access to credit at low prices. Odhiambo (2009) looked at the causal relationship between the development of financial institutions and poverty alleviation in Kenya and Uddhin (2014) in Bangladesh where their findings are if the financial system develops well, the multiplier effect arises is reduced poverty.

A good financial system is a massive and comprehensive one. Comprehensive means easily accessible and beneficial for the whole social strata. It is by the definition of the Financial Inclusion concept. Bank Indonesia (2014) defined financial inclusion as an effort to remove barriers in accessing financial services both price and non-price. Financial inclusion is also referred to as an additional solution and a powerful way to alleviate poverty (Chibba, 2009; Kiendrebeogo \& Minea, 2016).

Looking at the role of financial inclusion in poverty, the financial stakeholders strive to establish the role of financial institutions in a more tangible economic development. A visible role in economic development and community welfare realization is through credit distribution. Data from Otoritas Jasa Keuangan or Financial Services Authority (2017), until 2016, banking stakeholders have distributed loans up to 4,709.5 trillion rupiahs while the finance companies have channeled 387.5 trillion rupiahs. On the other hand, pension funds have increased to 228.8 trillion rupiahs higher than in 2015 . Each stakeholder of the financial institution, in addition to profit-seeking, also seeks to realize the community welfare through its service products. For more details, see Table 1 below:

In addition to the finance distribution, in terms of funding as well as the nominal of saving account numbers also happens to grow. OJK (2016) mentioned that within eight years, the total savings of commercial banks increased by 82.7 million (141\%). To achieve the goal of being easily accessible to the whole social strata, the LAKU PANDAI program is aimed at people who live in remote or rural areas. These various efforts increased Indonesia's financial inclusion index to 67.8 percent in 2016.

Table 1: The role of the Financial Service Industry in Indonesia.

\begin{tabular}{|l|l|l|}
\hline & \multicolumn{1}{|c|}{$\mathbf{2 0 1 3}$} & \multicolumn{1}{c|}{$\mathbf{2 0 1 6}$} \\
\hline Banking Credit Distribution & Rp. 3.585,8 Trillion & Rp. 4.709,5 Trillion \\
\hline Stock Market Capitalization & Rp. 4.219,0 Trillion & Rp. 5.753,6 Trillion \\
\hline Gross Insurance Premium & Rp. 193,1 Trillion & Rp. 212,9 Trillion \\
\hline Accounts Receivable of Funding & Rp. 348,0 Trillion & Rp. 387,5Trillionn \\
\hline Investment of Pension Fund & Rp. 157,6Trillionn & Rp. 228,8Trillionn \\
\hline
\end{tabular}

Source: Otoritas Jasa Keuangan and Bank Indonesia, (2017)

Despite the Financial Inclusion Index increment, what should be underlined is if the high Financial Inclusion Index has an impact on the number of poor people and an increment in living standards of the community. To find out these impacts, a poverty portrait is needed before and after the inclusion index exists. Referring to the Indonesian poverty data (Figure 1), there was indeed a poverty trend continued to decline from 1970 to 2014. In 1970, 60 percent of the Indonesian population was poor. In 1990 there was an improvement where the poor fell by 15 percent. The achievement in the 90s exceeded the proportion of the world's population living below the absolute poverty line. However, in 1997 Indonesia was heavily affected by the Asian currency crisis which caused the poor to rise 10.7 percent above the world average even though after the crisis period it gradually improved (Yusuf \& Sunmer, 2017). So, it can be concluded that poverty always has a sensitive conjuncture to change. This sensitivity is because poverty is a multidimensional phenomenon. There are many reasons why people might become poor thus the formulated anti-poverty policies are also multidimensional (Dawood et al., 2019; McCulloch \& Calandrino, 2003; Todaro, 2000; Weber \& Jensen, 2004). 
This study will examine the impact of household access to credit on poverty alleviation efforts in Indonesia. The idea is based on an explanation of the financial inclusion concept which is considered as an alternative way to reduce poverty from a unique channel namely financial institution. The reinforcing point for this idea is the success of Asian and African countries implementing credit as a powerful policy since it reaches the target of financial inclusion as well as anti-poverty. Also, some studies on dynamic poverty include aspects related to financial inclusion as the main variables releasing a person from poverty (Alisjahbana \& Yusuf, 2003; Dartanto \& Nurkholis, 2013; Dartanto \& Otsubo, 2016; Fields et al., 2003; Khandker, 1998b; Kim et al., 2009; Lanjouw \& Ravallion, 1995; Latifa et al., 2018; Wkh et al., n.d.; Xue \& Zhong, 2006).

\section{Research Background}

\subsection{What is Poverty}

In this study, we analyze the impact of access to credit at the household level on poverty status. Before performing the econometric estimation of such an impact, it would be better to understand poverty itself. According to the World Bank (2000), "Poverty is pronounced as depreciation in well-being". This then raises the question of what is meant by well-being and what is the basis for the deprivation measurement (Khandker \& Haughton, 2009). The most widely used approach in defining well-being is expressed by Sen (1988) in Khandker and Hougthon (2009) that welfare comes from the ability to function properly in a society. Therefore, poverty, in this case, arises when: "people lack key capabilities, and so have inadequate income or education, or poor health, or insecurity, or low self-confidence, or sense of powerlessness, or the absence of rigwht such as freedom of speech".

According to this view, poverty is a multidimensional phenomenon causing uneasy solutions to poverty. Mujumdar (2001) formulated three prominent features of poverty in Indonesia, one of which is multidimensional. Many people who are "not poor" in terms of income can be categorized as "poor" based on the lack of access to basic services as well as the low indicators of human development. The existence of these characteristics causes the measurement of poverty to be even more difficult. Poverty is often associated with inequality even though both are different things. Inequality is more visible in the income or expenditure distribution among the whole community (Khandker \& Haughton, 2009). Poverty emphasizes the inability to fulfill basic needs (Swastika et al., 2008).

Sukirno (1985) discussed poverty thoroughly in terms of the definition, causes, and consequences of poverty within the poverty circle concept. The poverty circle is a series of forces that influencing each other in such a way hence creating a situation where a country will remain poor (including at the household level) and will experience a lot of difficulties to achieve higher levels of development. According to Nurkse (1953), poverty is not only caused by the absence of development in the past but also creating obstacles to future development. According to him, the most important cycle of poverty is the conditions that cause obstacles to create high levels of capital formation. In this case, the financial institutions play a big role in capital, both on a small scale to MSMEs which are closely related to poverty, or even a bigger scale where many people are involved in the production process and new jobs are available. The capital establishment is caused by savings and another factor which is policy to attract foreign investors' interest to invest their capital. However, these factors are difficult to be realized in developing countries. Therefore, according to Nurkse's. the view there are two types of poverty preventing developing countries to achieve rapid development rates: in terms of supply and demand for capital.

Poverty is also closely related to factors of household characteristics. To understand poverty, it is necessary to review the demographic, geographic, and economic factors. Demographic factors are closely related to the population on the macroeconomic scale, and household size on the microeconomic scale. Latifa (2008) in her study showed several demographic factors were highly correlated in poor households such as the education level calculated from the length of education, the number of children, and the number of children under five years who passed away. Other findings from Zhang and Wei (1999); Alisjahbana and Yusuf (2003) confirmed that people might become poor due to low education, large household size, and other demographic variables.

Another factor closely related to poverty is the unemployment rate. Poverty is a phenomenon that can be identified in terms of the inability to actualize oneself so that cash programs should be provided, or even the inability to enter the labor market thus unemployment arises where the source of income is limited. Being unemployed will usually reduce one's living standards due to a lack of income. 
On the other hand, there is a phenomenon where someone has a job and is still extremely poor as the wage obtained is unable to meet the threshold that needs to be categorized as not poor (Abdullah \& Suhaib, 2011). Research by Egunjobi and Adenike (2014) explained that unemployment and poverty is an interrelated international phenomenon. The poor labor market somewhere makes many workers decided to leave their workplace. In certain cases, the low level of wage and the high level of inflation on basic goods make workers seeking another alternative income which is most likely illegal so that it causes other socio-economic problems such as crime rates increment, migration, and living standards drop (Akwara et al., 2013)

\subsection{The Role of Microfinance on Poverty Alleviation}

Poverty is closely related to limited access to resources, both economic and social. Therefore, the government established an entity to increase these resources and can be easily accessed by the whole social strata. Microfinance institutions are aimed to create financial inclusion for the poor, to improve household welfare, and to alleviate the poverty rate (Littlefield et al., 2003). OJK (2017) illustrated that microfinance has advantages in the flexibility aspect which can be easily adjusted to the needs and characteristics of the community, especially poor households. According to Addae-Korankye (2012), microfinance provides financial services to poor households with different conditions from financial services in general. Microfinance also covers all products in the form of savings, credit loans, and insurance. There are several types of microfinance throughout the world which can be seen in Table 2 below:

Table 2: Types of Microfinance Institutions.

\begin{tabular}{|c|c|c|c|c|}
\hline No & Type & Ownership & Funding Source & Example \\
\hline 1 & Project-Based & Private investor & Donor & $\begin{array}{l}\text { Informalized institution usually for a } \\
\text { development project, e.g. Morocco and } \\
\text { Russian microfinance development } \\
\text { projects from World Bank }\end{array}$ \\
\hline 2 & $\begin{array}{l}\text { Non-profit } \\
\text { Organization/ } \\
\text { foundation }\end{array}$ & Separate institution & Donation, grant & $\begin{array}{l}\text { The Sanduk in Comoros and Opportunity } \\
\text { International in Australia }\end{array}$ \\
\hline 3 & Cooperation & Member & $\begin{array}{l}\text { Capital, Deposit, } \\
\text { and Commercial } \\
\text { Fund }\end{array}$ & Face cam in Benin; KSP in Indonesia \\
\hline 4 & Private company & $\begin{array}{l}\text { Private and public } \\
\text { capital }\end{array}$ & $\begin{array}{l}\text { Capital, deposit, } \\
\text { and commercial }\end{array}$ & $\begin{array}{l}\text { RDS Islamic Bank Bangladesh Limited } \\
\text { (IBBL) and Grameen Bank in Bangladesh }\end{array}$ \\
\hline 5 & Public entity & $\begin{array}{l}\text { The central and } \\
\text { regional government, a } \\
\text { public limited company }\end{array}$ & $\begin{array}{l}\text { Government and } \\
\text { public }\end{array}$ & $\begin{array}{l}\text { Cajas in Municipales Peru and Bank } \\
\text { Rakyat Indonesia (BRI) in Indonesia }\end{array}$ \\
\hline
\end{tabular}

The concept of microfinance arises when there is a phenomenon of the need to provide credit to low-income groups and cannot be accessed by formal financial institutions with large credit. Conroy (2002) stated that microfinance is a provider of various financial services such as deposits, loans, payment services, money transfers, insurance, and training for poor and low-income households. This term has evolved from the concept of microcredit and microenterprise to provide an understanding which is equally important between savings and loans. In general, microfinance represents the field as a whole, whereas microcredit is more about providing credit (Vasanth et al., 2015)

Providing microcredit in microfinance by Khandker (1998a) is a counter-attack in response to the cause of one to be poor. According to him, the reason why one becomes poor can be categorized into two, first because of unemployment, and second because of limitations in physical and human capital. By providing microcredit, there will be new entrepreneurs who can earn additional income for their 
consumption needs. Since microfinance allows credit facilities without collateral, the program is considered to be effective and suitable for the poor who do not have physical collateral.

\subsection{Research Area}

We use the survey data from the Indonesia Family Life Survey (IFLS) 4 in 2007 and (IFLS) 5 in 2014 which covered nearly 80 percent of the entire Indonesian population and the data is longitudinal thus we can track respondents and follow their progress from period one to another period. This research does not divide the territory of Indonesia into east and west as we try to cover all regions. This level of research is households in Indonesia. The selection of households is based on household characteristics, namely receiving credit. Credit recipient households are a treatment variable to see changes in household poverty status after receiving the credit from financial institutions.

This research uses two quantitative approaches with Propensity Score Matching (PSM) and Double Differences (DD) methods. The collaboration of the two methods is carried out to find out the effect of an intervention (treatment) on the investigated outcomes by showing similarities in the characteristics of the two sample groups being compared (Khandker et al., 2010). The strengths of both methods are that they can answer the research hypothesis, which is access to credit influences poverty status changes.

PSM is applied to get a sample group that will be used in DD estimation based on the probability of a household receiving credit with some observable household characteristics. The adoption of PSM will set aside households that do not have similar characteristics. Combining PSM and DD can include observable and non-observable characteristics with constant assumptions over time (Khandker et al., 2010). DD is used to estimate the effect of financial inclusion on household poverty status

\section{Methodology and Data}

In this study, we use two methods to analyze the research objectives. The first method is Propensity Score Matching to look for common characteristics of credit recipient households. Propensity Score Matching can generate two groups of households that are accessed by financial institutions and households that are not accessed by financial institutions but have similar characteristics. It can be written in an equation $P(X)=\operatorname{Pr}(T=1 \mid X)$ which means the group of households accessed by financial institutions $(P)$ is the same as households who are not accessed by financial institutions $(T=1)$ in terms of program participation based on characteristics X. Propensity Score Matching graphically illustrates the similarity of the two groups in the common support area. The wider the common support area, the better the PSM matching results. Common support areas should meet the assumptions: $0<P(T=1 \mid X)<1$. Heckman (1999) stated that the assumptions ensure that the treated groups must have a close score or nearly the same as the control group. This assumption is important since it is only in the common support area that can be used as the basis for concluding the relationship between the treatment group and the control group.

PSM testing in this study was carried out by dividing households into two groups, namely credit recipient households and non-credit recipient households. The next step is to estimate these groups' probability of participating in a program based on certain characteristics where in this context is the probability of the household having access to financial institutions. The estimation is carried out using the Probit model and generates a probability of program membership or propensity score. The probability of program participation forms a common support area and households outside the common support area are set aside in the next PSM testing process, namely the balance test. A balance test (Balancing test) is carried out to ensure that the average of each characteristic and the average propensity score on each quantile of propensity scores are the same: $(P *(X / T=1)=P(C / T=0)$. followed by comparing households accessed by financial services institutions and households who are not accessed by financial service institutions with Double Differences techniques.

The second method is Double Differences, where a large estimate of changes will occur before and after the program with a parallel-trend assumption. The parallel trend means characteristics that can influence program participation and there is no observation that the value is always constant or does not change over time (Khandker \& Haughton, 2009). This unobservable heterogeneity can cause selection bias problems. The combination of Double Differences and PSM can answer the problem of selection bias by keeping the sample used in the common support area. 
DD estimation in this study was carried out by using panel data. It requires data availability in the baseline period which in this study is the 2007 data. Estimation is done by measuring the outcomes and covariates for groups of households accessed by financial institutions and households who are not accessed by financial institutions before and after the financial inclusion policy. The fixed effects panel regression model is used to maintain the time-invariant heterogeneity that cannot be observed and the heterogeneity of observable characteristics over many periods. Khandker and Houghton (2009) explained DD estimation with the fixed efficiency panel regression model in an equation as follows:

$$
\begin{gathered}
Y_{i t}=\phi Y_{i t}+\delta X_{i t}+\eta_{i t}+\varepsilon_{i t} \\
\left(Y_{i t}-Y_{i t-1}\right)=\phi\left(Y_{i t}-Y_{i t-1}\right)+\delta\left(X_{i t}-X_{i t-1}\right)+\left(\eta_{i}-\eta_{i}\right)+\left(\varepsilon_{i t}-\varepsilon_{i t}\right) \\
\Delta Y_{i t}=\phi \Delta T_{i t}+\delta \Delta X_{i t}+\Delta \varepsilon_{i t}
\end{gathered}
$$

The equation above explains that the Yit outcome can be estimated in Tit treatment with Xit covariates and time-invariant heterogeneity that cannot be observed by $\eta$ i which is well-correlated with treatment or other characteristics that cannot be observed by cit. Decreasing equation $1 a$ is done considering the change in time and generate equation $1 \mathrm{~b}$. Keep in mind that heterogeneity of ni is timeinvariant, so the variable is excluded from the equation. The treatment impact is $\varphi$ with ordinary least square (OLS).

\subsection{Data}

The data used in this study were obtained from the Indonesian Family Life Survey (IFLS) in 2007 and 2014. The IFLS data is a longitudinal survey data or micro survey data that includes individual, household, and community data in Indonesia. IFLS data is collected and compiled by the RAND Corporation based on a household survey conducted in 13 out of 27 provinces in Indonesia. The 13 provinces are DKI Jakarta, West Java, East Java, South Kalimantan, South Sulawesi, South Sumatra, West Nusa Tenggara, Central Java, D.I Yogyakarta, Bali, North Sumatra, West Sumatra, and Lampung. The survey results generated a sample representing approximately $83 \%$ of the Indonesian population and contained more than 30,000 people living in 13 of the 27 provinces.

This research uses two quantitative approaches, so a comprehensive operational explanation of variables is needed. The PSM and DD methods require the use of two types of variables. The variables have been selected based on relevant theories and previous researches therefore it is sufficient to present the research needs to find out the effect of access to credit on poverty status change at the household level in Indonesia. The two types of variables are the dependent variable and the independent variable. In the Propensity Score Matching model based on the probability of a household receiving credit, the dependent variable is access to credit dummy, whereas the independent variable is collateral ownership dummy, the status of property ownership dummy, natural disaster dummy, and gender dummy. In the Double Differences model, the dependent variable is the household poverty status dummy meanwhile the independent variable consists of 3 dimensions, namely the economic dimension, demographic dimension, and social dimension.

\subsection{Econometric Specification}

The margin of the treatment variables change is obtained after calculating the impact of household access on credit. The impact calculation will be close to reality since the characteristics of credit recipient households have been matched before. Characteristics of credit recipient households are explained through the following probability models:

$$
\mathrm{P}_{i}=\alpha+\beta_{1} \operatorname{Col}+\beta_{2} \text { Kota }+\beta_{3} B A+\beta_{4} P H K+\epsilon_{i}
$$

Where, $\epsilon_{-} i$ is an error term and assumed to be normally distributed, $\beta$ is the coefficient of each credit recipient household characteristic determinant, and $P_{-} i$ illustrates the probability of a household in receiving credit. The credit recipient household model is a preliminary way to filter populations hence a dataset will be constructed containing households with the same characteristics.

$$
Y_{i t}^{*}=\alpha+\beta T_{i t}+\rho t+\Upsilon\left(T_{i t} x t\right)+\sum_{j=1}^{n} \beta C O V_{j i t}+\epsilon_{i t}
$$


$\mathrm{Y}_{\mathrm{B}} \mathrm{it}^{\wedge *}$ is the outcome of household poverty status, where $\left(^{*}\right)$ shows each poverty status either to be poor or not. $\alpha$ shows intercept, while Tit a dummy variable of receiving credit treatment. $t$ is a dummy variable showing the period of before and after receiving credit, $\beta$ shows treatment coefficient which is household characteristics supporting one to fall into poverty or escape it. The effect of credit on poverty status calculation will be seen when the average value of credit influence is multiplied by the probability of household poverty status change.

\subsection{Operational Definition}

In this section, we first estimate the Propensity Score Matching against the probability of a household receiving credit. The score results from matching the credit recipient household characteristics which then will be used to estimate the status change of poor households in Indonesia as the core of this study. In the first model, we take 5 variables with four independent variables and one dependent variable. Here is how we construct these variables:

Table 3: The list of operational variables definition using Propensity Score Matching Model.

\begin{tabular}{|c|c|c|}
\hline Dependent Variables & Description & $\begin{array}{l}\text { Level of Measurement and } \\
\text { Data Management }\end{array}$ \\
\hline Credit Dummy (the debtor) & $\begin{array}{l}\text { This variable explains the credit recipient } \\
\text { household who got the credit application } \\
\text { approved. }\end{array}$ & $\begin{array}{l}\text { Nominal } \\
1=\text { credit approved } \\
0=\text { credit rejected }\end{array}$ \\
\hline $\begin{array}{l}\text { Collateral Dummy } \\
\text { (col) }\end{array}$ & $\begin{array}{l}\text { Collateral required by the creditor. Value } 1 \text { for a } \\
\text { collateral possession, and value } 0 \text { for no possession } \\
\text { of the collateral. }\end{array}$ & $\begin{array}{l}\text { Nominal } \\
1=\text { have collateral } \\
0=\text { do not have collateral }\end{array}$ \\
\hline Property & Status of Property Ownership is a socio-economic & Nominal \\
\hline Ownership Dummy (house) & $\begin{array}{l}\text { assessment indicator determined by the creditor. } \\
\text { Assessment is aimed to consider the credit } \\
\text { approval. }\end{array}$ & $\begin{array}{l}1=\text { owned } \\
0=\text { rent }\end{array}$ \\
\hline $\begin{array}{l}\text { Natural Disaster } \\
\text { (Natdis) }\end{array}$ & $\begin{array}{l}\text { It refers to the geographic situation where the } \\
\text { household lives. A region with intense natural } \\
\text { disasters will also be considered in credit approval. }\end{array}$ & $\begin{array}{l}\text { Nominal } \\
1=\text { natural disaster has ever } \\
\text { happened } \\
0=\text { natural disaster has never } \\
\text { happened }\end{array}$ \\
\hline Gender Dummy (sex) & $\begin{array}{l}\text { Sex representing gender aspect is taken into } \\
\text { account in credit approval }\end{array}$ & $\begin{array}{l}\text { Nominal } \\
1=\text { Male } \\
0=\text { female }\end{array}$ \\
\hline
\end{tabular}

The second model of this study is Double Differences which consists of one dependent variable namely household poverty status and treatment variable namely access to credit as well as seven control variables describing the demographic, economic, and social dimensions. Following these variables are as follows:

Table 4: The list of operational variables definition using Double Differences Model.

\begin{tabular}{|c|c|c|}
\hline Dependent Variables & Description & $\begin{array}{l}\text { Level of Measurement and } \\
\text { Data Management }\end{array}$ \\
\hline $\begin{array}{l}\text { Time Dummy } \\
\text { (year) }\end{array}$ & $\begin{array}{l}\text { This variable explains the credit recipient } \\
\text { household who got the credit application } \\
\text { approved. }\end{array}$ & $\begin{array}{l}\text { Nominal } \\
1=\text { credit approved } \\
0=\text { credit rejected }\end{array}$ \\
\hline $\begin{array}{l}\text { Treatment Dummy } \\
\text { (debit) }\end{array}$ & $\begin{array}{l}\text { Collateral required by the creditor. Value } 1 \text { for a } \\
\text { collateral possession, and value } 0 \text { for no possession } \\
\text { of the collateral. }\end{array}$ & $\begin{array}{l}\text { Nominal } \\
1=\text { have collateral } \\
0=\text { do not have collateral }\end{array}$ \\
\hline $\begin{array}{l}\text { Interaction } \\
\text { (debtor x year | dinner) }\end{array}$ & $\begin{array}{l}\text { Status of Property Ownership is a socio-economic } \\
\text { assessment indicator determined by the creditor. } \\
\text { Assessment is aimed to consider the credit } \\
\text { approval. }\end{array}$ & $\begin{array}{l}\text { Nominal } \\
1=\text { owned } \\
0=\text { rent }\end{array}$ \\
\hline \multicolumn{3}{|l|}{ Demographic characteristic } \\
\hline $\begin{array}{l}\text { Gender Dummy } \\
\text { (sex) }\end{array}$ & $\begin{array}{l}\text { Sex representing the gender aspect is taken into } \\
\text { account in credit approval. }\end{array}$ & $\begin{array}{l}\text { Nominal } \\
1=\text { Male }\end{array}$ \\
\hline
\end{tabular}






\section{Results and Discussions}

\subsection{Propensity Score Matching Estimation Result on Credit Recipient Household}

The Propensity Score Matching (PSM) estimation is done by combining IFLS 4 data in 2007 and IFLS 5 in 2014. In 2007 (IFLS 4) there were 506,470 households and combined with 664,669 households in 2014 (IFLS 5) and resulting in 1,171,139 households in total. After being combined, an estimated PSM matching was carried out in 2007 and made the base year of a matching analysis with the breakdown of the household numbers including credit recipients as many as 102,965 households and 403,505 noncredit recipient households (Table). Initially, 506,470 households in 2007 (IFLS4) were excluded by the estimated PSM and the remaining 495,087 households where credit recipient households became 101,912 households due to the unequal characteristics of credit recipients.

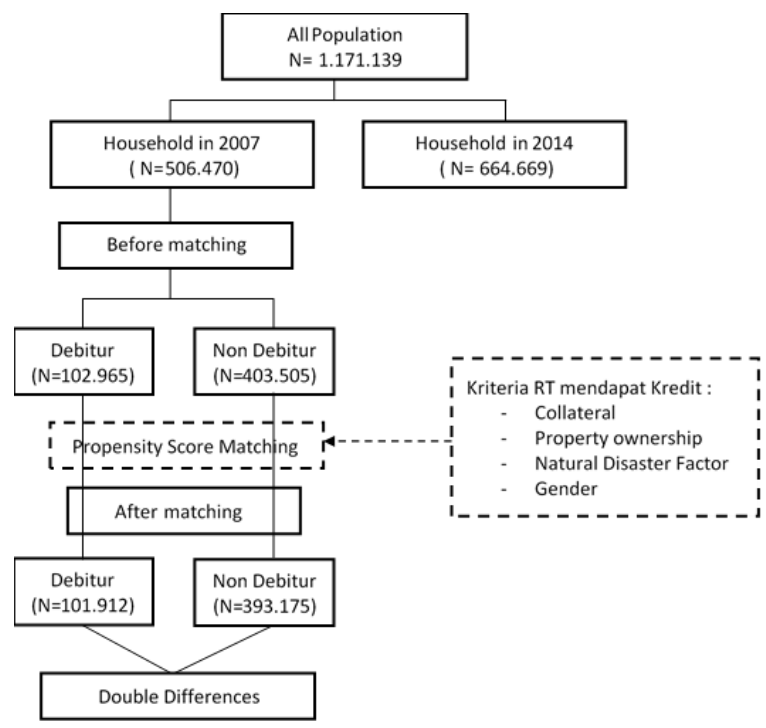

Figure 1. Flow chart of credit recipient household construction. 
Propensity Score Matching estimation is done to look for the characteristics of household credit recipient households. Table (6) addresses the characteristics of credit recipient households, namely collateral ownership, the status of property ownership (rent or owned), gender (male and female), and natural disaster factors. These four characteristics are obtained after attempting to select some of the similarities to get the best balancing test. Khandker (2010) mentioned that in finding the best characteristics that represent a data match, it must be performed until the balancing test value is satisfactory.

Table 5: Balancing Test Propensity Score.

\begin{tabular}{cccc}
\hline $\begin{array}{c}\text { Inferior of a block } \\
\text { of propensity } \\
\text { score }\end{array}$ & Credit Recipient & Household & Total \\
\cline { 2 - 4 } & & & \\
\hline 0.15 & 64.018 & 13.751 & 77.769 \\
0.175 & 75.805 & 15.591 & 91.396 \\
0.1875 & 84.116 & 20.449 & 104.565 \\
0.2 & 95.254 & 25.230 & 120.484 \\
0.2125 & 53.424 & 15.003 & 68.427 \\
0.3 & 18.750 & 10.611 & 29.361 \\
0.4 & 1.808 & 1.277 & 3.085 \\
\hline Total & 393.175 & 101.912 & 495.087 \\
\hline
\end{tabular}

Picture (3) shows the results of a good balancing test because visually there are many overlap areas between groups of credit recipient households and non-credit recipient households (Caliendo \& Kopeinig, 2008; Khandker et al., 2010). Table (6) shows the control variables that explain the characteristics of credit recipient households. All control variables show significant values in statistics.

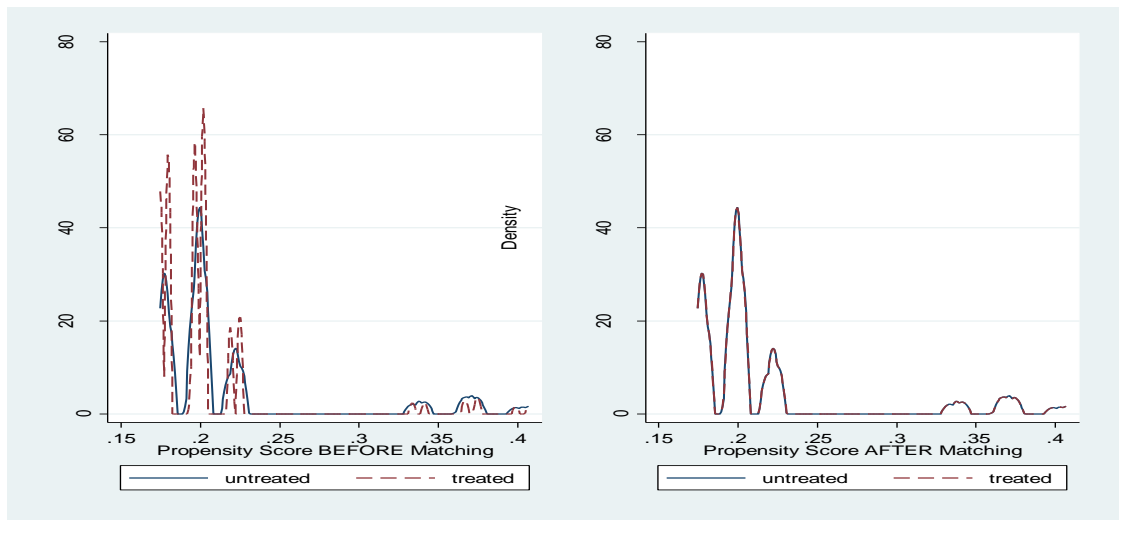

Figure 2. Regions of Common Support (Propensity Score) of Credit Recipient and Non-credit Recipient Households.

Table 6: Propensity Score Matching estimation result of credit recipient household.

\begin{tabular}{lrrrrrr}
\hline $\begin{array}{c}\text { Variable } \\
\text { Test }\end{array}$ & $\begin{array}{c}\text { Number of } \\
\text { Observation }\end{array}$ & $\begin{array}{c}\text { Mean } \\
\text { Propensity }\end{array}$ & Collateral & Housing & $\begin{array}{c}\text { Natural } \\
\text { Disaster }\end{array}$ & Sex \\
\hline $\begin{array}{l}\text { Credit } \\
\text { recipient }\end{array}$ & 495.087 & 0.21 & $0.861^{* * *}$ & $0.146^{* * *}$ & $0.135^{* * *}$ & - \\
& & & & & & $0.0342^{* * *}$ \\
& & & $(0.0121)$ & $(0.00717)$ & $(0.00809)$ & $(0.00710)$ \\
\hline
\end{tabular}

Numbers within parenthesis are standart errors

Notation: ${ }^{* *} \mathrm{p}<0.01,{ }^{* *} \mathrm{p}<0.05,{ }^{*} \mathrm{p}<0.1$

In the credit application process, financial institutions will conduct the evaluation and selection of potential customers based on the company's internal eligibility criterion. These criteria usually consist of several indicators illustrating the risk of potential customers. If the potential customer has an acceptable level of risk, the financial institution can provide credit, but if the perceived risk is too large and related to the ability to pay obligations, the application will be rejected. The regulation also explains that the availability of financial institutions does not guarantee a large number of credit recipient households. 
Based on PSM estimation, collateral ownership is the first factor in determining whether or not a household receives the credit. Households whose collateral has a greater probability of receiving credit than those who do not have collateral. Elsas and Krahnen (2000) stated that collateral has a large role in providing credit in all types of financial institutions. Stiglitz and Weiss (1981), considered collateral as a reason for banks to tolerate adverse selection and asymmetric information between creditors and debtors. Low-risk debtors usually have loans with high collateral value whereas high-risk debtors choose loans without collateral. This collateral is then used by financial institutions as a guideline in case of default in the future. Bester (1994) in his model explained that the existence of collateral gives power to financial institutions in negotiation when the default happens, whereas on the other side it makes the debtors more responsible.

The next factor is the status of property ownership, either rent or own. The status of property ownership by financial institutions is used as one of the qualitative indicators and is related to collateral. Those who live in their own house are more likely to get credit than those who rent. However, it does not mean that those who live in the rented house do not have collateral, because collateral can be in the form of movable objects (fiduciary) or immovable (mortgage rights). However, financial institutions and banks generally will be more likely to approve households whose collateral in the form of a housing property as it is more binding and personal.

Another interesting factor is unexpected factors such as natural disasters. When estimating the PSM and balancing test, it was found that natural disasters have a connection to the decision to give credit. Limited studies are discussing the relationship between natural disasters, but some studies can explain the relationship on this topic. Ninno et al (2003) revealed that after the flood disaster in Bangladesh in 1998, the demand for credit increased but financial stakeholders became more stringent in providing loans except for households whose already portfolios and previous exposures. Berg and Schrader (2012) also found similarities related to credit restrictions after the eruption of a volcano in Ecuador. The reason for the limitation is that after the natural disaster, asymmetric information has become greater because financial institutions such as banks have become unable to properly assess the quality of potential debtors.

The last factor is the reason for gender bias. Female household heads have a lower probability of receiving credit than males. A banking study conducted by the SME Assistence (2008) For Eastern Indonesia Program found that banks do not consider women as the main target of their products although the creditworthiness level of women is not much different than male debtors, and even better in some cases. Coleman (2000) argued that discrimination against women could be in the form of a few approved loans. This is because banks view that women entrepreneurs would have a lower tendency for success than men since they have lower education levels and also less experience in doing business. According to Barro \& Sala-i-Martin (1992), women entrepreneurs usually have a smaller business scale compared to men. Therefore, assets and sales are also lower so when applying for credit, it is difficult as it is not feasible enough. Also, the characteristics of households in Indonesia where men play a role as an income earner, makes creditors reluctant to provide credit if those who apply for credit are women, considering payment sources (first way out) and collateral (second way out) that are usually owned by men.

\subsection{The Result of Double Differences}

Double Difference (DD) estimation is conducted to obtain counterfactual value on outcomes. Two groups of households whose similar characteristics namely credit recipient households will be compared with their respective outcomes before and after receiving credit. Control variables are also included in DD testing to get the net effect of credit on household poverty status (outcomes). The use of fixed fixe defections is done to control the characteristics of unobservable households and time variants that can affect the outcome values (Khandker et al., 2010).

Table 7: Double Differences estimation result on household poverty status.

\begin{tabular}{lrrr}
\hline VARIABLE & Poor & Odd ratio & Marginal Effect \\
\hline & & & \\
Year (dyear) & -0.00251 & 0.997 & -0.002 \\
$1=2014,0=2007$ & $(0.0393)$ & $(0.0392)$ & $(0.26)$ \\
Debtor (debitur) & -0.0893 & 0.915 & -0.016 \\
$1=$ credit approved & $(0.0554)$ & $(0.0507)$ & $(1.69)$ \\
$0=$ credit rejected & & & \\
Debtor x Year (dinter) & $-0.167^{* *}$ & $0.846^{* *}$ & -0.032
\end{tabular}




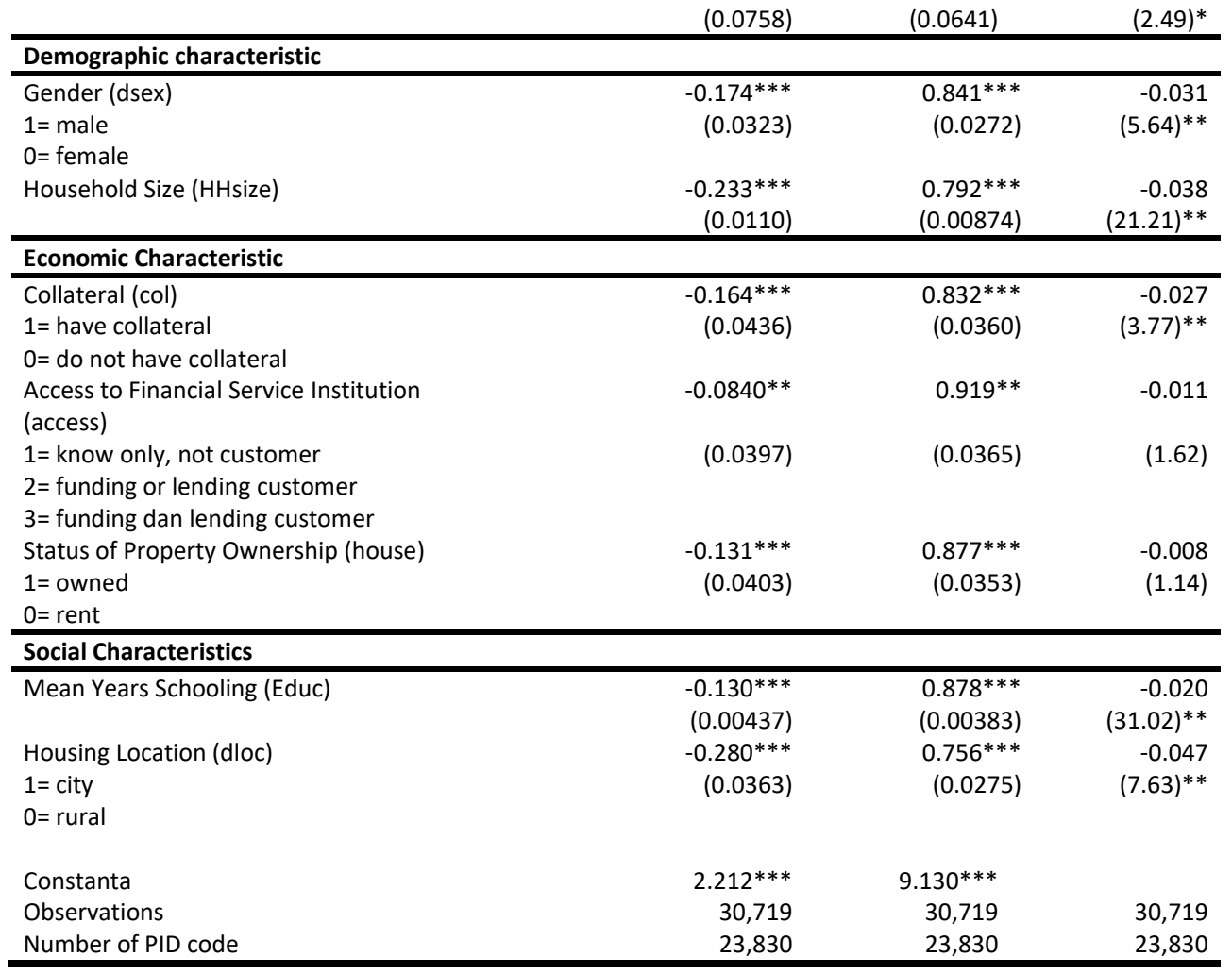

DD testing with PSM will be applied to 495,087 households whose a similar propensity score. The amount was obtained from the estimated PSM by setting aside 11,383 households. The results of DD estimation through PSM estimation in advance in table (7) show that the majority of dependent variables are affected by the existence of credit received by households. The majority of variables negatively impact poverty status in the poverty model. The impact is shown by the negative probability margin on the line "Debtor $x$ Year" in the table (7) or Tit $x \mathrm{t}$ in the research model. This means an increase in the probability of people escaping poverty because it approaches the number one for each increase in the probability of a household receiving credit (Figure 4).

The results of the PSM and DD analysis also found that credit, gender, collateral ownership, location of residence, access to financial services institutions, length of education, simultaneously influence poverty status. Partially, it is proved that credit, gender, collateral ownership, location of residence, length of education of the household's head, and the size of the household have a significant effect on poverty status, meanwhile, access to financial institution services has an insignificant effect on poverty status.

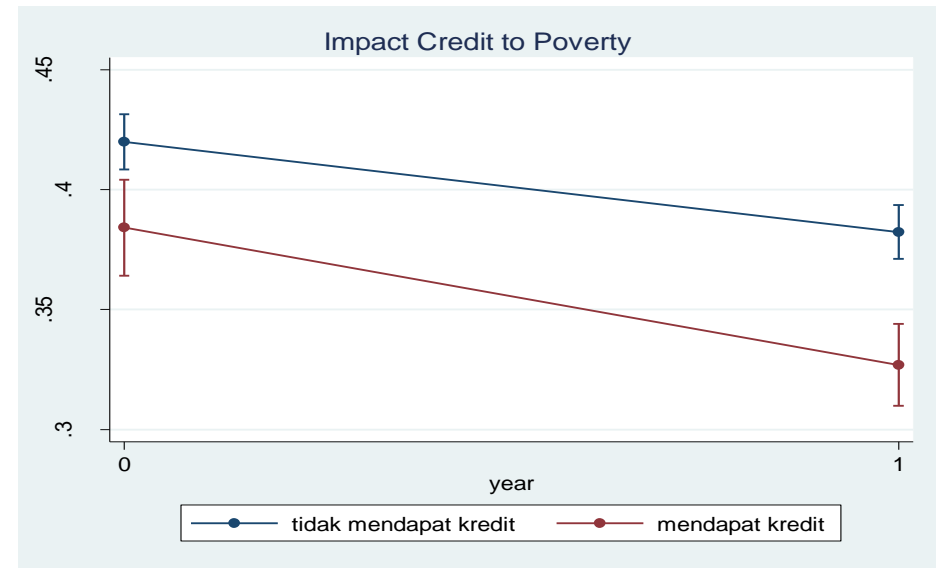

Figure 3. Effect of receiving credit on household status poverty. Source: IFLS year 2007 and 2014. 
The dependent variable is significantly affected by credit recipient households (Figure 4.7). The poverty status has a probability margin of 0.032 points and a coefficient of 0.19 points with a significance level of 5 percent which means that if a household receives credit, then the probability of the household becoming one poor decreases by 3.2 percent compared to households that do not receive credit.

\subsection{Research and Discussion Results}

The conducted PSM and DD analysis proved to be able to support the hypothesis of this study, that credit hurts household poverty status. It means households who have accessed and received a credit will have a lower chance of falling into poverty. By receiving credit, households become more productive and their household purchasing power or consumption will increase. Pitt and Khandker (1998) stated that credit recipient households have higher per capita income than those who do not receive so that per capita expenditure and household welfare also point to higher outcomes than those who do not receive and conclude that poverty rates in the recipient group are lower than with groups that do not receive. The urgency of the credit is the reason why the government genuinely strive to build financial inclusion as massive as possible (Otoritas Jasa Keuangan, 2017).

The government also attempts to alleviate poverty through credit, one of which is through the household-scale entrepreneurial transmission. According to Bah et al (2015), household-scale entrepreneurship in the form of Micro, Small, and Medium Enterprises (MSMEs) contributed 58.1 percent to GDP, 97.2 percent to new employment opportunities, and 14.1 percent to export revenues in 2012. According to Firdausy (2005), MSMEs play an important role in accelerating poverty alleviation. Providing credit to household-owned MSMEs will increase their capital and business capacity to create new jobs. Therefore, the role of credit is extremely important to encourage the household business's capacity thus a more optimal impact will be obtained. Figure (4.8) shows that the lower the proportion of MSME credit, the higher the poverty rate and vice versa.

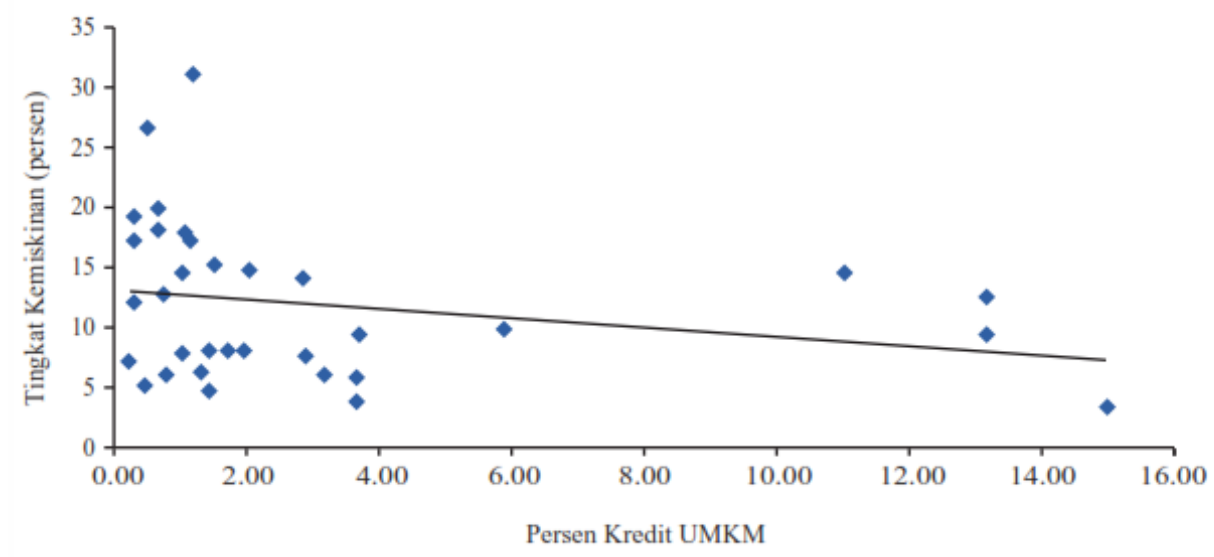

Figure 4. The relationship between poverty and credit proportion. Source: P2E-LIPI (2012).

This finding has implications for anti-poverty policies with credit instruments at the household level. The government has additional options for poverty alleviation with specific targets and policies. These specific targets and policies are intended to reduce poverty from financial institution channels. An example of the poverty policies implementation through financial institutions is subsidized loan interest, current account loans, and loan tenor allowances. Current account loans specifically will be best applicable for debtor households whose a business previously. Long-term interest and loan subsidies provide flexibility for household consumption. Consequently, their consumption quality will improve by itself. Households will be able to allocate their sources of income to better consumption utilities, for instance, secondary and tertiary goods and even investments that generate future benefits.

The role of financial services institutions as a way to empower the community and alleviate has been widely studied, one of which is research conducted by Damayanti and Adam (2015), mentioning productive loans such as KUR was able to make debtors more confident in developing businesses, creating assets, and broaden employment opportunities, while consumptive-designed loans are intended to guard the people's purchasing power, even credit is often used as a source of payment for health and education matters. However, credit benefits will not be maximized if household access to financial institutions, and vice versa experience obstacles. In this study, household access to financial institutions has no significant 
effect on poverty status and household consumption levels. The easiest explanation is due to the perception of the financial institution itself. Financial institutions such as banks maintain a net performing loan (NPL) as a business health indicator thus they prefer feasible and bankable households. Feasible means that households can pay all of their credit obligations, while bankable is related to the ability to meet credit requirements of financial institutions, where one of them is collateral ownership (Yushita, 2017). On the other hand, there there's a set of moral hazards and adverse selection found when households access financial institutions particularly for credit (Damayanti \& Adam, 2015)da. In poor households, even though financial infrastructure has spread almost throughout Indonesia Otoritas Jasa Keuangan (2017), they access financial institutions only to withdraw social assistance funds from the government or private sector so that the financial Institutions presence does not significantly change their poverty status (Coulibaly et al., 2016).

\section{Conclusions}

Based on the results that have been through the process of analysis and discussion, then conclusions can be formulated from this research as follows:

1. There is a 6.54 percent increment in the number of households receiving credit and have access to finance. 20.52 percent of the total number of credit recipient households are poor. Meanwhile, the number of poor households who did not receive credit was 79.48 percent. Most of the total poor households live in rural areas.

2. Based on Propensity Score Matching analysis, there are 1,171,139 households and marginalized by category into 495087 households comprising as many as 101912 credit recipient households and 393175 households who do not receive the credit. The characteristics of credit recipient households are considered marginalizing these households, i.e the collateral ownership, status of property ownership, history of natural disaster, and gender.

3. Based on the entire Double Differences analysis both with PSM or not, it was found that household credit hurts poverty status, and has a positive effect on household consumption. It was found that credit recipient households had a greater probability of escaping poverty than those who did not receive credit. The probability of having a much greater consumption can also be obtained by receiving credit compared to households who do not receive credit.ani

4. The control variables that significantly affect household poverty status are the head of the family gender, collateral ownership, location of residence, access to financial institutions, length of education, and household size. Status of residential property variable is proven insignificant on household poverty status while those that have a significant effect on household consumption are the head of the family gender, collateral ownership, location of residence, the status of residence, length of education, and size of the household. The variable access to financial institutions does not significantly influence household consumption.

\subsection{Recommendation}

Based on the conclusion above, an anti-poverty policy through credit transmission seems to be an alternative solution for the poverty problem. Picture 4.7 shows that credit is proven to be able in encouraging household consumption directly through consumptive activities or productive activities in form of venture capital. However, some preconditions are needed to enable credit to be an effective policy. Some of them are:

\section{Subsidized Interest of Consumptive and Productive Credit}

The government loan interest subsidy program is the main precondition. Interest is the price that the customer has to pay for the credit taken. Households will be greatly helped by a low interest in both consumptive and productive financing products low-interest consumptive loans enable households to add their assets and access basic services such as health care and education. On the other hand, low-interest productive loans will make it easier for them to develop their businesses due to new capital injection, thus production capacity increases and have an impact on new employment opportunities.

\section{Placing Public Fund with Low Cost of Fund}

Placing government funds on a product with a low cost of funds is the second precondition. The government can place several bags of funds with low returns on financial institutions that provide low credit as the covenant. Financial institutions still have to pay a high share of interest to the 
government with a moderate risk profile due to the threat of capital adequacy ratio (CAR) if funds are withdrawn during this time. With a lower cost of funds, financial institutions will have the ability to reduce lend rate tool to be more accessible to the whole social strata.

\section{Improving Financial Literacy and Knowledge of the Society}

Finance is an important aspect of most people's life. Financial knowledge possession determines one's decisions in choosing financial products. Financial decisions have a direct impact on living standards and even well-being. Knowledge about finance is important for individuals so that they are not making wrong financial decisions later. However, financial product services for the poor should include savings, money transfers, insurance services, and leasing options that are good in financial literacy. Lack of financial literacy will result in losses for individuals both as a result of inflation and a decline in economic conditions. A misunderstanding causes financial losses, as a result of wasteful spending and unwise consumption. Lack of financial literacy makes it difficult for individuals to invest or access financial markets even at a higher level.

\section{Credit Approval Adjustment based on Average Regional Economic Ability}

In general, banks or other formal financial institutions registered in the Financial Services Authority have internal guidelines regarding granting financing to the prospective debtor. The guidelines have been prepared based on risk management that prioritizes prudence which has been regulated by OJK through Financial Services Authority Regulation (POJK) No. 18 / POJK.03 / 2016 concerning Application of Risk Management for Commercial Banks. The rule applies nationally, thus 'one price' is for all regions in Indonesia. This concept is good for simplifying business processes but there are unconsidered factors related to differences in communities' ability between one region and another. It would be better if the credit provided is adjusted to regional macroeconomic indicators such as regional minimum wage (UMR), purchasing power, or regional inflation, therefore it will be more attractive and also be by the natural ability of prospective debtor in certain regions.

\section{References}

Abdullah, M., \& Suhaib, A. (2011). The impact of Zakat on the social life of Muslim society. Pakistan Journal of Islamic Research.

Addae-Korankye, A. (2012). Microfinance: a tool for poverty reduction in developing countries. Journal of Business and Retail Management Research, 7(1), 138-157.

Awkward, A. F., Akwara,;, Ngozi F, Enwuchola,; John, Adekunle,; Udaw,;, \& Joseph E. (2013). Unemployment and Poverty: Implications for National Security and Good Governance in Nigeria. International Journal of Public Administration and Management Research, 2(1), 1-11.

Alisjahbana, A., \& Yusuf, A. A. (2003). Poverty dynamics in Indonesia: panel data evidence. Department of Economics, Padjadjaran University.

Bah, A., Nazara, S., \& Satriawan, E. (2015). Indonesia's Single Registry for Social Protection Programmes. Research Brief, 49.

Barro, R. J., \& Sala-i-Martin, X. (1992). Convergence. The Journal of Political Economy, 100(2), 223-251.

Berg, G., \& Schrader, J. (2012). Access to credit, natural disasters, and relationship lending. Journal of Financial Intermediation, 21(4), 549-568. https://doi.org/10.1016/j.jfi.2012.05.003

Bester, H. (1994). The role of collateral in a model of debt renegotiation. Journal of Money, Credit and Banking, 26(1), 72-86.

Caliendo, M., \& Kopeinig, S. (2008). Some practical guidance for the implementation of propensity score matching. Journal of Economic Surveys, 22(1), 31-72.

Chibba, M. (2009). Financial inclusion, poverty reduction, and the millennium development goals. The European Journal of Development Research, 21(2), 213-230.

Coleman, S. (2000). Access to capital and terms of credit: A comparison of men- and women-owned small businesses. Journal of Small Business Management, 38(3), 37-52.

Coulibaly, A., Yogo, U. T., Coulibaly, A., Thierry, U., Access, Y., \& Devel-, W. P. (2016). Access to Financial Services and Working Poverty in Developing Countries To cite this version: HAL Id: hash01403001 Access to Financial Services and Working Poverty in Developing Countries.

Damayanti, M., \& Adam, L. (2015). TNP2K.

Dartanto, T., \& Nurkholis. (2013). The determinants of poverty dynamics in Indonesia: evidence from panel data. Bulletin of Indonesian Economic Studies, 49(1), 61-84. https://doi.org/10.1080/00074918.2013.772939

Dartanto, T., \& Otsubo, S. (2016). Intrageneration Poverty Dynamics in Indonesia: Households' Welfare 
Mobility Before, During, and After the Asian Financial Crisis. JICA-RI Working Paper, 117, 1-42. https://www.jica.go.jp/jica-ri/publication/workingpaper/jrft3q00000027bc-att/rJICA-

RI_WP_No.117.pdf

Dawood, T. C., Pratama, H., Masbar, R., \& Effendi, R. (2019). Does financial inclusion alleviate household poverty? Empirical evidence from Indonesia. Economics \& Sociology, 12(2), 235-252.

Del Ninno, C., Dorosh, P. A., \& Smith, L. C. (2003). Public policy, markets, and household coping strategies in Bangladesh: Avoiding a food security crisis following the 1998 floods. World Development, 31(7), 1221-1238.

Egunjobi, T. A. (2014). Poverty and Unemployment Paradox in Nigeria. IOSR Journal of Humanities and Social Science, 19(5), 106-116. https://doi.org/10.9790/0837-1954106116

Elsas, R., \& Krahnen, J. P. (2000). Collateral, default risk, and relationship lending: An empirical study on financial contracting. CFS Working Paper.

Fianto, B. A., Gan, C., Hu, B., \& Roudaki, J. (2018). Equity financing and debt-based financing: Evidence from Islamic microfinance institutions in Indonesia. Pacific-Basin Finance Journal, 52, 163-172.

Fields, G. S., Cichello, P. L., Freije, S., Menéndez, M., \& Newhouse, D. (2003). Household income dynamics: A four-country story. Journal of Development Studies, 40(2), 30-54. https://doi.org/10.1080/00220380412331293757

Firdausy, C. M. (2005). Trends, issues, and policies towards international labor migration: An Indonesian case study. United Nations Expert Group Meeting on International Migration and Development, New York, USA, 68.

Haughton, J., \& Khandker, S. R. (2009). Handbook on Poverty+Inequality. The World Bank.

Jalilian, H., \& Kirkpatrick, C. (2005). Does financial development contribute to poverty reduction? Journal of Development Studies, 41(4), 636-656. https://doi.org/10.1080/00220380500092754

Khandker, S. R. (1998a). Fighting poverty with microcredit: experience in Bangladesh. In Fighting poverty with microcredit: experience in Bangladesh (p. 228). Oxford University Press.

Khandker, S. R. (1998b). Poverty. Oxford University Press.

Khandker, S. R., \& Haughton, J. (2009). Handbook on poverty and inequality. World Bank.

Khandker, S. R., Koolwal, F. G. B., \& Samad, H. A. (2010). Handbook on Impact Evaluation: Quantitative Methods and Practices. World Bank.

Kiendrebeogo, Y., \& Minea, A. (2016). Financial development and poverty: evidence from the CFA Franc Zone. Applied Economics, 48(56), 5421-5436.

Kim, J., Engelhardt, H., Prskawetz, A., \& Aassve, A. (2009). Does fertility decrease household consumption? An analysis of poverty dynamics and fertility in Indonesia. Demographic Research, 20(June 2009), 623-656. https://doi.org/10.4054/DemRes.2009.20.26

Lanjouw, P., \& Ravallion, M. (1995). Poverty and household size. Economic Journal, 105(433), 1415-1434. https://doi.org/10.2307/2235108

Latifa, A., Aswatini, A., \& Romdiati, H. (2018). Population and Social Demographics Poverty: a Case Study in the Border Areas of East Kalimantan and North Sulawesi. Journal of Indonesian Social Sciences and Humanities, 1(1), 175-191. https://doi.org/10.14203/jissh.v1i1.13

Littlefield, E., Morduch, J., \& Hashemi, S. (2003). Is microfinance an effective strategy to reach the millennium development goals? Focus Note, 24(2003), 1-11.

McCulloch, N., \& Calandrino, M. (2003). Vulnerability and chronic poverty in rural Sichuan. World Development, 31(3), 611-628.

Morduch, J. (1999). The microfinance promise. Journal of Economic Literature, 37(4), 1569-1614. https://doi.org/10.1257/jel.37.4.1569

Mujumdar, N. A. (2001). World development report, 2000/2001: attacking poverty. Indian Journal of Agricultural Economics, 56(1), 146.

Nurkse, R. (1953). Problem of Capital Formation in Underdeveloped Countries. Oxford University Press.

Otoritas Jasa Keuangan. (2017). Strategi Nasional Literasi Keuangan Indonesia (Revisit). Otoritas Jasa Keuangan.

P2E LIPI. (2012). KUR di Era Otoonomi Daerah: Membangung Sinergi antara Kelembagaan Pasar, Pemerintah Daerah dan Komunitas dalam Pengeloalan Kredit Program untuk Pemberdayaan UMKM.

Pitt, M. M., \& Khandker, S. R. (1998). The impact of group-based credit programs on poor households in Bangladesh: Does the gender of participants matter? Journal of Political Economy, 106(5), 958996.

Program for Eastern Indonesia SME Assisten. (2008). Akses ke pendanaan bagi perempuan pengusaha di 
Indonesia. Ringkasan Eksekutif.

Sen, A. (1988). Freedom of choice. Concept and content. European Economic Review, 32(2-3), $269-294$. https://doi.org/10.1016/0014-2921(88)90173-0

Stiglitz, J. E., \& Weiss, A. (1981). Credit Rationing in Markets with Imperfect Information. The American Economic Review, 71(3), 393-410.

Sukirno, S. (1985). Ekonomi Pembangunan (Development Economics). LPEF-UI Bima Grafika.

Swastika, D., Hardono, G., Supriatna, Y., \& Bastuti, T. (2008). Poverty in the era of decentralization in Indonesia. CAPSA Working Paper, 102, 73-130.

Todaro, M. P. (2000). Pembangunan Ekonomi di Dunia Ketiga Edisi Ketujuh. Jakarta: Erlangga.

Uddin, G. S., Shahbaz, M., Arouri, M., \& Teulon, F. (2014). Financial development and poverty reduction nexus: A cointegration and causality analysis in Bangladesh. Economic Modelling, 36, 405-412. https://doi.org/10.1016/j.econmod.2013.09.049

Vasanth, V., Selvam, M., Lingaraja, K., Miencha, I. O., \& Raja, M. (2015). Testing the Environmental Kuznets Curve Hypothesis at Firm Level in India. Journal of Sustainable Development, 8(8), 201-212. https://doi.org/10.5539/jsd.v8n8p201

Weber, B. A., \& Jensen, L. (2004). Poverty and place: A critical review of rural poverty literature.

Wkh, S. I., Zlwk, Q., lurp, V., \& Wkh, D. Q. G. (n.d.). 6Kruw Whup 3Ryhuw | | Qdplfv ( Ylghqfh lurp. 60.

Xue, J., \& Zhong, W. (2006). Unemployment, poverty, and income disparity in urban China. Unemployment Inequality and Poverty in Urban China, 1999, 43-64. https://doi.org/10.4324/9780203446515

Yushita, A. N. (2017). Pentingnya literasi keuangan bagi pengelolaan keuangan pribadi. Nominal: Barometer Riset Akuntansi Dan Manajemen, 6(1), 11-26.

Yusuf, A. A., \& Sunmer, A. (2017). Poverty, Inequality, and Structural Change in Indonesia.

Zhang, W. . dan Z. W. (1999). Poverty Problem in Urban China, in Zhongguo Jumin SHorufenpei Yanjiu. China Finance and Economics Publisher. 